\title{
Onde vivem os bárbaros?: traduções e cena
}

\section{Where do the barbarians live?: translations and scene}

Luciana Santos Gonçalves ${ }^{1}$ 


\section{Resumo}

Onde vivem os bárbaros é uma montagem da companhia chilena Bonobo, na qual se aborda o modo como a violência das relações humanas é normalizada e compreendida atualmente e como se configura o arquétipo do inimigo, que sempre acompanha a história dos povos e civilizações. A obra conta a história de três primos que, depois de vários anos sem se ver, decidem se encontrar no Chile, em 2015. O anfitrião, Roberto, diretor de uma ONG famosa, vê-se envolvido no estranho homicídio de uma jovem. Esse fato desencadeia uma série de revelações e atitudes inesperadas dos personagens, que aguçarão os conflitos e ideias que cada um construiu ao redor do outro: o inimigo. Este texto apresenta e discute sua tradução no Brasil.

Palavras-chave: Alteridade; inimigo; violência; democracia; tradução; legendagem

\section{Abstract}

Where the barbarians live is staged by the Chilean company Bonobo, which approaches the way the violence of human relations is normalized and understood today and how the archetype of the enemy is configured, which always accompanies the history of peoples and civilizations. The play tells the story of three cousins who, after several years without seeing each other, decide to meet in Chile in 2015. The host, Roberto, director of a famous NGO, finds himself involved in the strange murder of a young woman. This unleashes a series of revelations and unexpected attitudes of the characters, which will sharpen the conflicts and ideas that each one built around the other: the enemy. This text discusses its translation in Brazil.

Keywords: Otherness; enemy; violence; democracy; translation; subtitling

E-ISSN: 2358.6958

\footnotetext{
1 Mestre em Estudos Hispânicos, pela Universidade de Cádiz/Espanha. Atualmente trabalha como professora de língua espanhola na Escola de Formação Gerencial do Sebrae em Belo Horizonte (MG) e é Tradutora Pública e Intérprete Comercial concursada pela Jucemg. sgluciana@gmail.com
} 


\section{Onde vivem os bárbaros²}

A Bonobo Teatro é uma companhia chilena fundada em 2012, centrada em compreender por que e como se legitima a violência com o 'outro' em um contexto democrático.

O texto de Dónde viven los bárbaros foi escrito por Pablo Manzi, ator, diretor e dramaturgo chileno, idealizador da Cia. Bonobo, com seus demais integrantes. Formados na Academia de Atuação Fernando González Mardones e na Escola de Teatro da Universidade do Chile, eles se uniram em 2012 para montar Amansadura, já com a indagação sobre violência, tolerância e democracia, e em 2015, montam Dónde viven los bárbaros, que traz a mesma indagação, pautada na construção do outro, do bárbaro.

Pablo Manzi tem apenas 30 anos de idade e já ganhou vários prêmios de dramaturgia. Ele considera que o dramaturgo não é o autor de uma obra, mas sim, o grupo, e essa dinâmica dá espaço para gerar diálogos, posições políticas e enfrentamentos. Ele entende que a criação do texto dramático é inseparável do fenômeno cênico, por isso, o processo criativo das montagens da Cia. Bonobo se dá sempre em torno da palavra e da ação, por meio de improvisações dirigidas e registradas. ${ }^{3}$

Ao contrário do teatro chileno que deu voz aos oprimidos, as obras de Manzi e da Cia. Bonobo voltam seus olhos aos novos opressores. Segundo Manzi, para existir um oprimido, é preciso que haja opressores.

É muito estranho que, de repente, ninguém se julgue opressor neste mundo aparentemente progressista. A experiência democrática está borrando os opressores e só aponta os oprimidos, os processos e formas de opressão. Mas é difícil reconhecer quando nós mesmos exercemos opressão sobre o outro. (Manzi, 2018)

Em Dónde viven los bárbaros, o diretor de uma ONG cujo objetivo é democratizar regiões em situações de conflito, de repente se vê como opressor e não foge ao julgamento de seus entes mais próximos, os quais também ora desempenham o papel do oprimido, ora o do opressor. Nesse contexto, situações de violências, das mais graves às mais sutis, são relativizadas ou mesmo justificadas, a depender dos atores nelas envolvidos e seus papéis sociais.

A montagem reafirma a trajetória do grupo na cena teatral chilena. Obteve excelente recepção do público e da crítica especializada, recebendo distinções e reconhecimentos, além de convites para festivais na Europa e na América Latina. A peça Donde viven los bárbaros teve sua estreia no Chile em 2015 e no mesmo ano levou o prêmio de Melhor Dramaturgia pelo Círculo de Críticos de Arte do Chile. A estreia no Brasil ocorreu em 2018, no Festival Internacional de Teatro Palco \& Rua de Belo Horizonte (FIT), quando tive a oportunidade de fazer sua tradução para legendagem.

Um ano depois da tradução audiovisual, traduzi o texto dramático na íntegra e

2 Pablo Manzi. Dónde viven los bárbaros. O texto - fonte utilizado para a tradução integral da peça foi recebido, em versão digital, arquivo PDF, de Lygia Santos, da Frames, empresa responsável pela legendagem eletrônica do FIT-BH 2018. Correspondência eletrônica. 05. set. 2018. A tradução do texto integral de "Dónde viven los Bárbaros", da Cia. Bonobo de Teatro, foi autorizada pelo dramaturgo, em correspondência eletrônica entre os dias 22 e 24 de abril de 2019.

3 Cia Bonobo. Texto de apresentação do grupo. Disponível em: https://bonoboteatro.wixsite.com/bonoboteatro . Acesso em: 19 de jun. 2019. 
pude perceber na prática as diferenças entre a tradução para legendagem, na qual o novo texto é totalmente dependente do texto original - e com o qual convive concomitantemente - e a tradução literária, que gera um novo texto, independente, ainda que derivado do original.

A tarefa do tradutor audiovisual é executar uma dupla tarefa de retextualização: a primeira, da fala para a escrita e a segunda, da língua fonte para a língua de chegada (Koch, 2000). A tradução, por si só, é considerada um exercício de retextualização, porque o texto original passa pelo filtro do tradutor, que negocia sua cultura com a cultura do outro, a fim de gerar um texto recriado. Na passagem da língua oral à escrita, realizamos uma segunda tarefa, que é a de eliminar algumas marcas estritamente interacionais ou inserções desnecessárias, além de retirar elementos redundantes do texto original (Koch, 2000). Do ponto de vista linguístico, podemos dizer que a legenda é o resultado de uma retextualização ou transcodificação, e do ponto de vista tradutório, a legenda é o resultado de um processo intersemiótico (Machado, 2007).

$\mathrm{Na}$ tradução para legenda, o tradutor se vê exposto ao escrutínio do espectador - que acompanha a leitura do texto e muitas vezes o compara com o original - e limitado ao número de caracteres, o que o obriga a realizar algumas adaptações, de forma que a máxima informação caiba no menor espaço. Jorge Díaz Cintas (2001, p.123-124) fala da constante redução do material original, uma vez que "a legenda não é nem pode ser uma tradução integral dos diálogos a versão original". Além disso, levando em conta que o tradutor tem esse limite de espaço para projetar as legendas, essa condensação se mostra mais necessária ainda. De acordo com o pesquisador, primeiro, o tradutor audiovisual tem que eliminar da mensagem o que não é relevante para a compreensão do texto, segundo, tem que reformular o que considera essencial para o desenrolar do filme - ou peça teatral, neste caso - da forma mais concisa possível (Cintas, 2001). Já o texto literário traduzido não se submete tão facilmente à avaliação do leitor, porque é um texto novo e independente do original. A não ser aquele leitor extremamente exigente e conhecedor da língua fonte, que pode cotejar o original com a tradução. A tradução foi um grande desafio, porque o texto é denso, longo e tenso, mas também engraçado e irônico.

Embora sua trama pudesse se passar em qualquer outro lugar do mundo, carrega vários elementos locais, como gírias, piadas, construções sintáticas e elementos particulares do Chile, como o picolé Chocolito e a cerveja Escudo. Essa presença gerou dúvidas: a melhor solução seria adaptá-lo ao contexto brasileiro ou manter as referências culturais chilenas? A princípio, na tradução para legenda, optei por adaptar os termos à realidade brasileira, adotando as marcas "Eskibon", para Chocolito e "Brahma", para Escudo. Entendi que assim chamaria atenção para ato tradutório. No entanto, poderia também gerar estranheza ao espectador. Fui alertada, em outra ocasião, de que não existia, nesta tradução, nenhuma outra adaptação à realidade brasileira, nem sequer quanto aos nomes dos personagens. Portanto, na tradução literária, acabei optando pelos termos genéricos "picolé" e "cerveja". Foi mais coerente com todo o processo tradutório do texto dramático. Algumas escolhas dos tradutores podem ser ousadas e inovadoras, e inclusive bem acolhidas pelos espectadores/ leitores. No entanto, é preciso ser cuidadoso para seguir uma linha congruente de 
raciocínio. Na legendagem, o espectador está exposto ao texto original, por isso talvez o ideal seja optar-se por uma tradução mais fiel ao texto estrangeiro. Se fosse o caso de uma dublagem, modalidade na qual o texto original desaparece, dando lugar a um novo texto, não haveria problema em realizar mudanças mais radicais e incluir aspectos da cultura de chegada - o que acontece em praticamente todos os filmes infantis. Mas não foi o caso na tradução para legenda da obra chilena.

Dónde viven los bárbaros é um texto necessário para nosso momento atual, já que não só no Brasil, como em várias partes do mundo, estamos vivenciando um ataque à democracia, um escancaro dos preconceitos, da intolerância, da violência e do ódio. Em Dónde viven los bárbaros, o papel reflexivo da arte é intenso e torna-se difícil sair ileso da carga de diálogos em que algozes são vítimas e vice-versa.

A obra é um convite à reflexão: será que por trás da intenção da inclusão se encontra também uma violência dirigida àqueles que, de alguma forma, não cumprem com a ideia hegemônica do que significa ser um cidadão?

\section{Onde vivem os bárbaros?}

Pablo Manzi e Cia Bonobo

Tradução Luciana Gonçalves

\section{Prólogo}

Atenas. Século V a.C. O Médico se defende perante o Conselho Militar de Atenas.

Para onde vão me mandar? Senhores do Conselho. Estão acusando um médico, sabiam? (Ri, nervoso). Ninguém sabe o que vai acontecer. Ninguém sabe quem mora na floresta. Ninguém sabe o que há debaixo da roupa. (Ri, nervoso). Ninguém sabe quem matou aquela mulher. E não tem problema dizer: não sei. Não sei. Aqui a língua é uma arma. A minha não é afiada, me dizem na assembleia. Não tenho essa coisa típica daqui típica de Atenas. (Pausa). Bem, vou ser... não quero faltar o respeito a ninguém. Acho que aqui às vezes falamos um pouco demais. Aqui falamos, falamos, até esconder tudo. Queremos esconder tudo. O que está acontecendo nesta polis. O que tem debaixo da roupa. O que tem lá fora, na floresta. Os buracos nesta polis. E aqui há um buraco que vocês estão preenchendo mal. Essa mulher ter aparecido morta afeta todo mundo. Ela é ateniense, antes de qualquer coisa. Ela não merecia o que lhe aconteceu e eu também não mereço isto. Vão me culpar de quê? As coisas aqui em Atenas estão pegando fogo. A verdadeira guerra não vai ser com gente de fora. Só me resta curar gente daqui atacada por gente daqui. E não é para menos. Os camponeses andam com muita raiva. Eu os vi quando fomos fazer o registro de pestes. Estão com as barbas brancas, mas não de pelo. É de baba seca acumulada perto da boca. Ficam agitados quando reclamam, e cospem demais, porque começam a falar muito rápido quando os visitamos. E têm sangue nos olhos ao contar como arrancaram suas terras. Me falaram que os camponeses eram violentos e supersticiosos. Mas são 
misteriosos que cheiram a ovelha e a poucas expectativas. De suas bocas saem ideias estranhas sobre a vida, sobre o trabalho. Mas também saem voando dentes e doenças mortais. Estão com os olhos fundos, de tanta terra que lhes foi tomada. Como se, no avançar da vida, os olhos viessem para dentro. E sei que os atenienses estão ajeitando as coisas, na medida do possível. Mas aqui as terras lhes são arrancadas com armas, ou seja, conversando nem sempre se pacificam as coisas. Agora, por exemplo, estão fazendo um manuscrito para ver quem pode participar da assembleia. Não veem que agora está batendo forte essa coisa nova chamada de "democracia". Quer dizer governo de todos. Dizem que a base é o diálogo. Mais gente falando. Aonde quero chegar, senhores do Conselho... Um pouco disperso, sou assim, também me criticam na assembleia. A única vez que matei alguém foi tentando curar. Gostaria de saber se estou falando sozinho, senhores. Para que vão me mandar para lá? Quando fui visitar o camponês, vi seus olhos vermelhos e lhe perguntei o que tinha acontecido. "A vida, amigo, foi isso o que aconteceu", sussurrou, secando a boca. Fiquei olhando para ele, enquanto limpava minha roupa, parecia que um de seus dentes tinha caído no meu peito. E fiquei pensando. A vida. O que acontece se a vida aparecer? Não conseguia dormir. E agora que me aconteceu isso, que estão me acusando disso, que vão me levar para procurar sei lá o quê fora de Atenas, estou me fazendo a mesma pergunta. E pelas caras dos senhores, já estou vendo que... O que vão fazer comigo? Vão me mandar para a floresta, não é? Para procurar o quê, senhores? Onde está a guerra? Para que vamos procurar um inimigo que ninguém conhece? Alguém já viu esses bárbaros, por acaso? Ninguém vai me dizer nada? Se acham muito importantes, senhores do Conselho Militar! Bárbaros! Façam-me rir! Isso aqui vai arder em chamas! E não vão ser os bárbaros que vão colocar fogo! Por que não podemos dizer não sei? "-Você sabe quem vive nas florestas? -Não sei. Não sei!" É tão grave dizer isso? Não suportam deixar buracos aqui. Não deixam uma pergunta sequer sem resposta. Ninguém viu esses bárbaros e já demos nomes a eles. Mas tem uma coisa que nós não sabemos. Tem um buraco pegando fogo debaixo desta polis. Um buraco que não dá para tampar falando. E não está na floresta! Está debaixo da roupa.

SÉCULO V a.C. CONSELHO MILITAR DE ATENAS. DOIS HOMENS DO CONSELHO MILITAR ESPERAM O MÉDICO

Conselheiro 1: Dizem que vai chegar agora.

Conselheiro 2: E qual dos dois vai contar pra ele?

Conselheiro 1: Ninguém contou?

Conselheiro 2: Não.

Conselheiro 1: Como vai receber a notícia?

Conselheiro 2: Como você receberia?

Conselheiro 1: Não, é... mas se ninguém contou, por que voltou?

Conselheiro 2: Porque está acompanhado.

Conselheiro 1: Com quem?

Conselheiro 2: Com quem encontrou na floresta.

Conselheiro 1: Quem encontrou na floresta? 
Conselheiro 2: Caro senhor, não sabe como é o castigo?

Conselheiro 1: Não.

Conselheiro 2: Mandaram esse homem procurar bárbaros.

Conselheiro 1: A pólis está cheia de bárbaros.

Conselheiro 2: Não, esses não. Mandaram-no procurar selvagens, sátiros.

Conselheiro 1: $O$ que é isso?

Conselheiro 2: Não sabe o que são sátiros? São bárbaros perigosíssimos.

Conselheiro 1: Qual é o perigo?

Conselheiro 2: São metade humanos, metade monstros. Têm desejos selvagens e são muito agressivos.

Conselheiro 1: Mas se parecem conosco?

Conselheiro 2: Sim, mas são duas vezes maiores. Têm orelhas e rabos de cavalo, e um pênis ereto gigante.

Conselheiro 1: Foi o que esse homem achou?

Conselheiro 2: É o que parece. (Silêncio)

Conselheiro 1: Então, agora um desses vai entrar por essa porta?

Conselheiro 2: Sim.

Conselheiro 1: Agora mesmo?

Conselheiro 2: Exato.

Conselheiro 1: Um sátiro vai entrar por esta porta?

Conselheiro 2: Receio que sim, meu caro. (Pausa)

Conselheiro 1: O tempo todo?

Conselheiro 2: $O$ quê?

Conselheiro 1: $O$ tempo todo ereto?

Conselheiro 2: Parece que sim.

Conselheiro 1: Deve ser um pouco desconfortável.

Conselheiro 2: Deve.

Conselheiro 1: Não deve ser uma cena agradável para a mãe dele.

Conselheiro 2: Provavelmente não.

Conselheiro 1: Ver o filho ereto o tempo todo.

Conselheiro 2: Sem dúvida.

Conselheiro 1: O que acontece quando ejaculam?

Conselheiro 2: Não sei.

Conselheiro 1: Mas o pênis é de cavalo ou de humano?

Conselheiro 2: Não sei, me parece que de cavalo.

Conselheiro 1: E os testículos?

Conselheiro 2: Não sei.

Conselheiro 1: Alguém já viu um sátiro antes?

(O médico entra com dois bárbaros: uma mulher e um homem. Todos ficam olhando. Um dos bárbaros quebra o gelo)

Bárbaro 1: Bem, não somos um mistério. Não estão nos descobrindo. Não temos o que vocês chamariam de lar. Não temos o que vocês chamam de terra, mas temos o que chamam de filhos. $O$ que vocês chamam de irmãos. Irmãos de sangue, quero dizer. Aqui pai e mãe são irmãos. Não é uma decisão. É algo que aconteceu. Nos 
penetramos muito. Não estamos orgulhosos disso, como vocês diriam. Poderíamos dizer que somos infelizes, como vocês dizem. Para nós, comer e penetrar são a mesma coisa, sabe? De qualquer forma, não fazemos amor, como se diria na sua língua. Então, não somos a utopia, como vocês dizem, como o homem aqui se cansou de perguntar. Ela e eu ficamos sem povo. Não sei como falar isso na sua língua, ficar sem povo. Estou tentando explicar a ela o que é um inimigo, como dizem aqui, para nos identificarmos, como vocês dizem, para não nos perdermos na floresta, para nossa história ficar impregnada no musgo, mas é um pouco difícil quando não se tem um território. Porque nem sempre existe uma terra para defender. Por isso está difícil encontrar um inimigo, alguém a quem temer.

Conselheiro 2: Meu caro, (pede para o médico se aproximar) estes não são os bárbaros que... sabe?

Médico: Está falando dos sátiros?

Conselheiro 2: Isso mesmo.

Médico: Pois bem, não vi nada disso na floresta. Só vi esses. E algo me diz que se me mandarem de novo, não vou encontrar nenhum sátiro. Então, se tiver que ir de novo, prefiro que me matem.

Conselheiro 2: Não o mandaremos de novo.

Conselheiro 1: Descobriram os responsáveis pelo homicídio.

Médico: Como?

Conselheiro 2: Pelo que soube, o senhor a conhecia.

Médico: Quem?

Conselheiro 2: A mulher assassinada. Eram próximos?

Médico: Quem a matou?

Conselheiro 2: Um grupo de soldados. Não sei se sabia, mas essa mulher se passava por homem.

Conselheiro 1: Parece que era para participar das assembleias.

Conselheiro 2: Naquela noite, uns soldados perceberam e...

Médico: Como ela morreu?

Conselheiro 2: Foi queimada. (O médico fica estupefato e pesaroso. Aproxima-se novamente do bárbaro) Este homem os levará com os militares que os conduzirão para fora da pólis.

Bárbaro 1: Preciso ficar aqui, por favor!

Conselheiro 2: Não, sinto muito, temos que acalmar as coisas na pólis, então chega de gente de fora, nem bárbaros...

Bárbaro 1: Lá fora não tem ninguém.

Conselheiro 2: Pode se juntar com seu povo.

Bárbaro 1: Que povo? Todos os meus irmãos são escravos ou comerciantes em alguma pólis. Ele prometeu que nos levaria à pólis do governo de todos.

Conselheiro 2: De todos os atenienses, claro.

Médico: E quem são os atenienses?

Conselheiro 2: Como?

Médico: Não percebem o que está acontecendo? Foram ver como os camponeses se organizam? Viram suas caras? Deem uma volta por lá e vejam suas assembleias 
cheias de gente que não tem casa, que não sabe ler, e de mulheres, porque não têm uma lista dos que podem participar. Lá o povo obedece porque o povo é quem manda. Lá percebi que as pessoas não estão unidas pelos deuses ou pelas pólis, estão unidas pelas doenças, pelas coisas que não têm, pelos rios que afetam a colheita, pelos buracos que têm no corpo e ouve-se uma palavra que nunca ouvi nas nossas assembleias... autonomia! A autonomia das pessoas, dizem por lá. Essa gente está fazendo uma pólis que vocês não veem, que arde debaixo desta, que é ateniense só para sobreviver, e digo porque sou médico de guerra. Quando tenho que cuidar dos soldados, todos os dias tiro a roupa deles e encontro belas surpresas. Vejo homens que têm buracos, buracos que têm o cheiro do musgo das florestas, de um corte no corpo, de uma pólis que é o corte da outra. Essa é a pólis que vocês não veem, e que está se organizando. E que vai nos fazer arder. Não percebem que os bárbaros que estão procurando não estão nas florestas.

Conselheiro 1: Onde estão?

Médico: Aqui. (Levanta a roupa e mostra que tem uma vagina)

Fim do prólogo

Chile. 2015. Roberto está sentado diante de seu psiquiatra.

Roberto: "Não olhe pra mim assim, merda", ela disse. Mas era um merda carinhoso. Nunca ouvi minha mãe falando palavrão. Só podia estar olhando para ela com cara de idiota. Eu a vi morrer. Ninguém acha que vai ver sua própria mãe morrer. Quero dizer que não acha que vai vê-la no momento em que para de respirar. Ela me falou coisas estranhas nesse dia. Falou para eu olhar meus irmãos. Sério. Ela me disse: "olhe seus irmãos". Que irmãos? Eu pensei. Meus próximos, pensei enquanto colocava meu casaco em suas pernas. Mas minha mãe parou de acreditar na Igreja quando se separou do meu pai, então não sei. Depois me disse para parar de sonhar. Fiquei perdido de novo. Estava deitada na cama e falou mais do que nunca. Trepa, ela me disse. Tem que trepar, Roberto. Sério. Trepa tranquilo. Trepa direito, trepa de frente. Fiquei surpreso, não estava preparado. Tive que expulsar muita gente que estava no quarto da minha mãe na clínica. Nesse momento final, minha mãe tinha conhecido muita gente. Ela estava muito sozinha. Quando a gente está sozinho, acaba conhecendo muita gente. Quando entrei no quarto, estava cheio de gente. Gente. Vou chamar pelo nome. Gente peruana. Não sei se é certo falar assim. Mas era isso. Eram peruanos que a beijavam e lhe contavam segredos ao pé do ouvido. Eu pensava, "por que esses peruanos têm segredos com minha mãe?" Acho que estou falando com você porque minha mãe não foi embora em paz, então eu não estou em paz. Conversei com ela durante uma hora antes de ela morrer. Ela só falou do ódio que sentia pelo amor. Pelo amor pelo meu pai, eu acho. Eu acho. O amor não vai nos salvar, ela disse. Não se apaixone. Só pelos seus amigos. Meu pai faleceu há muitos anos e teve várias mulheres depois da minha mãe. Meu pai não foi um pai. Mas era meu pai. Minha mãe foi uma mãe. E me disse antes de morrer que não se apaixonou pelo meu pai. Que ela se apaixonou pelas expectativas que tinha sobre meu pai. "Me apaixonei pelas minhas próprias expectativas", ela me disse. "Isso sempre acontece com a gente. E depois?" "Acontece a vida, Roberto. É o que acontece. Aparece a vida", ela disse enquanto secava a boca. "Não sonhe com nada. O único jeito de mudar o mundo é não sonhar 
com nada", ela disse outra vez com os olhos já fora de órbita. Ficamos em silêncio. Assim, olhando um para o outro. Fiquei pensando no que deve ser isso de aparecer a vida. Olhou pra mim mais uma vez e me disse: "cuide dos seus irmãos". Eu sei lá, sou filho único.

Chile. 2015. Na casa de Roberto estão sentados os três primos.

Roberto: Foi o que ela disse.

Ignacio: Mas você é filho único.

Roberto: Sou.

Ignacio: Então que irmãos você tem que olhar?

Roberto: Não sei.

Ignacio: Sua mãe estava meio estranha antes de morrer. No final, começou a fazer coisas estranhas. Eu a vi com muita gente.

Roberto: Que bom.

Ignacio: Mas também estava muito sozinha. Talvez a história do seu pai a tenha afetado muito.

Roberto: $O$ quê?

Ignacio: O que o seu pai fez.

Roberto: O que o meu pai fez?

Ignacio: Podemos não falar disso? O que você acha?

Roberto: Acho bárbaro. Mais vinho? (Levanta para pegar mais vinho)

Ignacio: Você ouviu?

Nicolás: $O$ quê?

Ignacio: Ele disse: "acho bárbaro" e foi pegar mais vinho.

Ignacio: O que quis dizer com isso?

Nicolás: Não sei.

Ignacio: Bárbaro.

Nicolás: Foi.

Ignacio: $O$ que quis dizer?

Nicolás: Não sei.

Nicolás: Bárbaro pode significar muitas coisas.

Ignacio: Pode, muitas.

Nicolás: Bárbaro pode significar muitas coisas.

Ignacio: Verdade.

Nicolás: Bárbaro pode significar muitas coisas.

Ignacio: Estamos de acordo.

Nicolás: Ele morou na Argentina.

Ignacio: Mas também morou na Nigéria.

Nicolás: Na Argentina quer dizer legal, não?

Ignacio: É.

Nicolás: O que significa bárbaro na Nigéria?

Ignacio: Eu vou saber?

(Roberto volta. Fica olhando para eles com a garrafa de vinho na mão)

Roberto: O que o meu pai fez?

Ignacio: Não precisamos falar disso agora. 
Roberto: Vocês estão estranhos.

Nicolás: Não, será?

Roberto: Onde estão morando?

Ignacio: Perto do monte, com minha família.

Roberto: Casado?

Ignacio: Sim.

Roberto: Filhos?

Ignacio: Também.

Roberto: Bárbaro. (Silêncio. Ignacio olha para Nicolás) Vocês têm se visto muito?

Ignacio: Agora não tanto, desde que Nico foi morar no centro.

Roberto: Está morando no centro?

Nicolás: Estou.

Roberto: E aí?

Nicolás: Bom, é estranho, às vezes, mas é bom.

Roberto: Por quê?

Nicolás: Por que o quê?

Roberto: Por que estranho?

Nicolás: Às vezes vemos coisas que não vemos aqui.

Ignacio: Mas às vezes o povo exagera. Já viu algo terrível de verdade?

Nicolás: Ontem vi uma mulher sendo morta na rua.

Ignacio: $O$ quê?

Nicolás: Isso mesmo.

Ignacio: E o que você fez?

Nicolás: Eu vi.

Ignacio: Mas o que estava fazendo?

Nicolás: Voltando para casa à noite.

Ignacio: Como sabe que a estavam matando?

Nicolás: Escutei um barulho muito alto, parecia o crânio dela estourando no cimento. Ignacio: Nossa! Como sabe que foi isso?

Nicolás: Quando vi de onde vinha o barulho, vi a cara dela com sangue e um grupo de homens chutando. E ela dizia, "socorro, socorro"!

Roberto: E o que você fez?

Nicolás: Comecei a entender o que estava acontecendo.

Ignacio: Eu imagino, mas o que você fez?

Nicolás: Fiquei com muito medo.

Ignacio: Em que momento?

Nicolás: Comecei a tremer e meu picolé caiu.

Roberto: Picolé?

Nicolás: É.

Ignacio: Você estava chupando um picolé?

Nicolás: Estava.

Ignacio: Enquanto matavam uma mulher na sua frente.

Nicolás: É... foi.

Ignacio: Quer dizer que mataram uma mulher... 
Nicolás: E estupraram.

Ignacio: O quê?

Nicolás: Acho que a vi ser estuprada antes de ser assassinada.

Ignacio: Como sabe que foi estuprada?

Nicolás: Vi alguns pênis pra fora no meio do tumulto.

Ignacio: Então, estupram e matam uma mulher na sua frente e você chupando picolé?

Nicolás: Tinha começado a comer antes do ocorrido.

Ignacio: Não ficou mal por deixá-la morrer?

Nicolás: Eu?

Ignacio: Não se sentiu mal?

Nicolás: Agora que ouço você falando assim, é estranho.

Ignacio: E antes?

Nicolás: É que eu já tinha visto essa mulher em outros episódios violentos.

Ignacio: Como assim?

Nicolás: Deve ser por causa da profissão dela.

Roberto: Qual é a profissão?

Nicolás: É prostituta.

Ignacio: Ah. (Pausa)

Roberto: Hum.

Ignacio: Era prostituta?

Nicolás: Era. (Silêncio)

Ignacio: Ah.

Nicolás: $O$ quê?

Ignacio: Não sei, não era uma... Senhora. Quero dizer, era. É. Não mais. Agora que ela faleceu, digo, a senhora. Muda de figura, de qualquer forma.

Roberto: É, muda.

Ignacio: Um pouco, muda um pouco. Quando soube que era prostituta, bem, continua sendo terrível, mas... (Silêncio)

Nicolás: Posso ir ao banheiro?

Ignacio: Claro! Não sei onde fica.

Roberto: Saindo da cozinha, antes da escada.

Nicolás: E se o cachorro me vir?

Roberto: Ele não faz nada, é inofensivo. No dia em que um ladrão vier, ele vai convidá-lo para entrar. (Nenhum dos dois ri. Nicolás sai. Silêncio)

Ignacio: Esses cachorros são simpáticos. Acha que Nico está bem?

Roberto: Como?

Ignacio: Acha que Nico está bem?

Roberto: Acho.

Ignacio: Eu não. Estou preocupado, por tudo o que aconteceu.

Roberto: $O$ quê?

Ignacio: Não sabe o que aconteceu com ele?

Roberto: Fiquei dez anos fora do Chile, não sei nada de ninguém.

Ignacio: Nicolás bateu a cabeça. 
Roberto: Sério?

Ignacio: Tropeçou num buraco.

Roberto: Num buraco?

Ignacio: Ele ficou assim, do jeito que você viu.

Roberto: Como?

Ignacio: Não percebeu nada?

Roberto: Não.

Ignacio: Falei com o tio. O pai dele, nosso tio.

Roberto: Isso, nosso tio. Somos primos.

Ignacio: Acontece o seguinte: acho que tem uma parte da vida que ele não vê.

Roberto: Sei.

Ignacio: Ele não vê o véu.

Roberto: O quê?

Ignacio: Não sei explicar.

Roberto: Bem...

Ignacio: É como se...

Roberto: $O$ quê?

Ignacio: É melhor não falar mais nada.

Roberto: Está bem.

Ignacio: Mas na verdade...

Roberto: $O$ quê?

Ignacio: Não, melhor não.

Roberto: Tudo bem.

Ignacio: Porque eu também não saberia explicar.

Roberto: Tudo bem, não precisa explicar.

Ignacio: Ele não vê, ah, é uma bobagem. Fique tranquilo.

Roberto: Estou tranquilo.

Ignacio: Porque ele não vê uma coisa da vida que não sei explicar.

Roberto: Pode falar de uma vez?

Ignacio: Ele não entende que na vida tem coisas que são como um véu. É como se não entendesse que existe... um véu. Que uma pessoa também é outras. E no fundo, não vê... o véu.

Roberto: Não estou entendendo.

Ignacio: Ele está vindo. Você vai entender, preste atenção.

(Nicolás entra)

Ignacio: A televisão está horrível ultimamente. Acho que subestimam as donas de casa. O que você acha, Nicolás?

Nicolás: Sobre o quê?

Ignacio: Acha que subestimam as donas de casa?

Nicolás: Que dona de casa?

Ignacio: As donas de casa. Você sabe. A dona de casa.

Nicolás: Não sei. Teria que ver que senhoras estão em casa agora vendo televisão, se é que estou entendendo. (Ignacio olha para Roberto)

Ignacio: Este país não é mais o mesmo. Deve ser culpa dos peruanos. Ou não? Dos 
peruanos, é.

Nicolás: Que peruanos?

Ignacio: Os peruanos, que vêm roubar nosso país.

Nicolás: Já ouvi falar outras vezes, mas não sei de que peruanos está falando. (Ignacio olha Roberto de novo. Silêncio. O cachorro late alto e interrompe a conversa)

Nicolás: E você?

Roberto: Eu o quê?

Nicolás: Como você está? Como é voltar ao Chile depois de tudo o que viu? Sua organização está famosa.

Roberto: A Fundação?

Ignacio: O que fazem?

Nicolás: Democratizam regiões em conflito.

Ignacio: Estou perguntando para ele.

Roberto: Ensinamos vias democráticas às pessoas que vivem em regiões de conflito. Ignacio: E se eles não quiserem?

Roberto: É o que sempre acontece. Não é fácil. Às vezes há lugares onde só relacionam a democracia com o homem branco, e esses lugares são pobres desde a chegada do homem branco.

Nicolás: Que homem branco?

Roberto: Não, quero dizer... "o homem branco".

Nicolás: Ah.

Roberto: Não sei, trabalho com gente muito agressiva. Muito agressiva.

Ignacio: É mesmo?

Roberto: Mas gente dócil. Conheci gente linda que estupra crianças por vingança, a pedido de Deus. Além do mais, não sei, você vai perdendo a fé nas pessoas. Algo muito bárbaro. Então tive que pôr minha fé em outras coisas.

Nicolás: Em quê?

Roberto: Em Cristóvão Colombo.

Nicolás: Cristóvão Colombo?

Roberto: Meu cachorro, ele se chama Cristóvão Colombo.

Nicolás: Mas por que se chama assim?

Roberto: Porque a primeira vez que o vi, chegou à minha casa como se quisesse chegar a outra. É como se não tivesse chegado aonde queria.

Nicolás: Mas por que Cristóvão Colombo?

Roberto: Porque Cristóvão Colombo queria chegar às Índias.

Nicolás: É?

Roberto: É, por isso os chamaram de índios.

Nicolás: Sério? Ele queria chegar às Índias?

Roberto: É, você não sabia?

Nicolás: Não, mas ele chegou aqui.

Roberto: Quem?

Nicolás: Cristóvão Colombo.

Nicolás: Então por que índios?

Roberto: Porque queria chegar às Índias. 
Nicolás: Mas chegou aqui.

Roberto: Chegou, Nicolás. Eu e Cristóvão Colombo, o cachorro, não precisamos de nenhum filtro. Posso olhá-lo nos olhos sem problema.

Nicolás: Um filtro?

Roberto: É, Nicolás, um filtro. Às vezes, na vida a gente tem que pôr...

Ignacio: Um véu.

Nicolás: Um véu?

Nicolás: Um véu, para não ver você chorando?

Roberto: Eu nunca chorei.

Nicolás: Nunca chorou ao ver as coisas que conta?

Roberto: Não, acho que não. Nunca tinha pensado nisso.

Ignacio: Mas alguma vez bateu em alguém?

Roberto: Nunca.

Ignacio: Esteve com os estupradores dessas meninas?

Roberto: Estive.

Ignacio: Eu dava um tiro neles.

Roberto: Eu trabalho com eles.

Ignacio: Você trabalha com pessoas que estupram crianças.

Roberto: A pedido de Deus, sim.

Ignacio: Deixe-me entender uma coisa: na Nigéria, você trabalha com negros...

Roberto: Nem todos na Nigéria são negros.

Ignacio: Esses eram negros?

Roberto: Eram.

Ignacio: Então. Esses negros têm um pênis, não quero parecer preconceituoso, então não vou falar do porte. Mas é o pênis de um negro, certo? E ele o introduz na vagina de uma criança negra.

Nicolás: De que tamanho?

Ignacio: O quê?

Nicolás: $O$ tamanho da vagina.

Ignacio: Não sei, Nicolás. Não tenho pensado muito em vaginas de crianças nigerianas ultimamente. (Volta a Roberto). Você disse que é capaz de conversar com esses estupradores?

Roberto: Não conversamos.

Ignacio: O que fazem?

Roberto: Dinâmicas de papéis.

Ignacio: Dinâmica de papéis?

Roberto: É.

Ignacio: Você faz dinâmicas com estupradores de crianças.

Roberto: É um exercício para gerar empatia entre as pessoas.

Ignacio: Empatia com estupradores de crianças?

Roberto: Fazemos exercícios fictícios nos quais as pessoas têm que simular um papel. Ficções para as pessoas poderem voltar a se enxergar. É tipo teatro.

Ignacio: Então está montando uma peça de teatro com estupradores de crianças com pênis de 7 metros. 
Roberto: Temos que pensar que eles veem a vida com esse véu. Crianças que foram ensinadas a odiar o inimigo desde que nasceram. Crianças que veem a vida pelo véu do seu Deus.

Ignacio: Quem são crianças?

Roberto: Eles.

Ignacio: Os estupradores?

Roberto: Sim, são menores de idade.

Ignacio: Ah.

Nicolás: $\mathrm{O}$ quê?

Ignacio: Nada, aí muda de figura. (Pausa). Posso fazer uma pergunta? Quando você diz "bárbaro", a que se refere? (O celular de Roberto toca)

Roberto: (No celular). Por que eu? Caiu.

Nicolás: $O$ que houve?

Roberto: Nada.

Nicolás: Tem certeza?

Roberto: Tenho. (Começa a se servir vinho. Tudo em silêncio)

Nicolás: Desculpe, mas sinto que aconteceu algo, se quiser, não precisa me contar, mas está tudo bem?

Roberto: Está.

Ignacio: Tem certeza?

Roberto: Não é nada.

Nicolás: $O$ que foi?

Roberto: Recebi uma ligação anônima com o recado de que vão me castigar com meus seres queridos para eu aprender.

Nicolás: Acabaram de dizer isso?

Roberto: Foi.

Nicolás: Agora?

Roberto: É.

Nicolás: A ligação que acabou de cair?

Roberto: Isso.

Ignacio: Nossa, você está bem?

Roberto: Estou. Mais vinho?

Ignacio: (Ignacio olha para Nicolás. O clima está tenso). Bem... (Silêncio) você não fica com medo?

Roberto: De quê?

Ignacio: De o castigarem com seus seres queridos

Nicolás: Para você aprender?

Ignacio: Era isso?

Nicolás: Era, disseram: "vamos castigá-lo com seus seres queridos para você aprender", não é?

Roberto: Não vai acontecer nada. (Silêncio)

Nicolás: Estranha a ordem da frase, não? (Risos nervosos)

Ignacio: Não falaram quando? (Risos nervosos)

Roberto: Não vai acontecer nada, estamos nos divertindo. 
Nicolás: Se você diz, então tudo bem.

Roberto: Estou bem. (Silêncio) Vinho chileno.

Nicolás: Não. Sim. (O clima está tenso)

Roberto: Uma senhora me deu ontem. Ela mesma faz. (Silêncio)

Ignacio: O que entendem por castigar? Desculpe, (ri, nervoso) é que acabou de acontecer algo muito estranho. Não estavam brincando. Ou estavam? Roberto?

Roberto: Não. (Silêncio). Vejam só. Vocês são meus primos. Não os vejo há mais de dez anos. Quero ficar tranquilo. Passar esta noite com as pessoas que amo.

Ignacio: Claro, com seus seres queridos.

Nicolás: Ignacio.

Ignacio: Desculpe, é que como você é meu primo, fico preocupado, só isso.

Roberto: Não precisa se preocupar. (O telefone toca de novo)

Ignacio: Não vai atender?

Roberto: Não. É a grega.

Ignacio: A grega?

Roberto: Estou trabalhando com uma grega, ela é um saco.

Nicolás: Sua colega de trabalho?

Roberto: Caiu no tapa com algumas pessoas do grupo. Depois chora com eles. Depois cai na farra com as pessoas do grupo com que trabalhamos e isso não é permitido.

(O cachorro late lá fora. Ignacio se assusta)

Ignacio: Devo ir lá ver?

Roberto: É Cristóvão Colombo latindo. Quer que vá ver? (Roberto se levanta e vai olhar lá fora)

Ignacio: O que está acontecendo?

Nicolás: Não sei.

(Roberto entra)

Roberto: Não é nada, não tem por que se preocupar.

Nicolás: Tem certeza?

Roberto: Ninguém vai entrar aqui.

Nicolás: Mas você está tendo problemas com alguém?

Roberto: (Pausa) Dois dias atrás tivemos um imprevisto.

Nicolás: Um imprevisto?

Roberto: Estamos trabalhando com um grupo de crianças.

Nicolás: Crianças?

Roberto: Jovens! Adolescentes de 15 a 18 anos.

Roberto: Acontece que tem uma menina de 16 anos que não fala comigo, não olha para mim.

Ignacio: Só com você?

Roberto: Ela fala com todos, menos comigo. Participa das atividades, mas, quando eu chego, fica imóvel. Não me olha nem vai embora.

Ignacio: Pode estar apaixonada.

Roberto: Não sei. Às vezes sinto que a conheço de algum lugar. Tem um rosto conhecido. Então chamamos a tia. 
Ignacio: Que tia?

Roberto: A tia da jovem.

Ignacio: E os pais dela?

Roberto: Não tem pais.

Ignacio: E aí?

Roberto: Ela foi.

Ignacio: Quem?

Roberto: A tia, pessoalmente. Eu lhe disse que sua sobrinha não podia participar mais.

Nicolás: E o que ela disse?

Roberto: Pediu para falar a sós com a sobrinha.

Ignacio: E o que você fez?

Roberto: Eu as levei à minha sala para conversarem tranquilas.

Ignacio: E o que fizeram?

Roberto: Entraram.

Ignacio: E onde você ficou?

Roberto: Lá fora.

Ignacio: Olha.

Roberto: Pois é.

Roberto: Deixei-as conversarem. Ela começou a falar muito palavrão.

Nicolás: E o que aconteceu?

Roberto: O tom da conversa subiu.

Ignacio: Por quê?

Roberto: Escutei barulho de pancada.

Ignacio: Você entrou?

Roberto: Não. Como é que ia entrar? Entendi que a menina estava batendo nela.

Nicolás: A menina batendo na tia?

Ignacio: Como você sabe?

Roberto: Não sei, eu supus.

Ignacio: Olha.

Nicolás: E depois?

Roberto: Escutei mais pancadas.

Ignacio: Aí você entrou.

Roberto: Não.

Ignacio: Tinha uma criança lá dentro.

Roberto: Uma jovem.

Nicolás: Mas parecia que ela estava batendo na tia.

Ignacio: Estou falando com ele.

Roberto: Se eu entrasse, jogaria no lixo todo o nosso trabalho.

Nicolás: $O$ que aconteceu então?

Roberto: Decidi entrar.

Ignacio: Por fim.

Roberto: É. A tia saiu de lá tremendo e pedindo desculpas. Eu a levei ao quintal. Ignacio: E a menina?

Roberto: A jovem. Estava inconsciente. Foi estranho. Porque a vi e realmente parecia 
que a conhecia de algum lugar. Levaram-na ao hospital.

Ignacio: E o que você fez?

Roberto: Fiquei com a tia. Estava destruída, muito envergonhada.

Nicolás: E a menina?

Roberto: Fiquei sabendo ontem que faleceu.

Nicolás: Como?

Roberto: A tia exagerou.

Nicolás: Nossa!

Roberto: É. (Silêncio)

Ignacio: Por que não entrou antes na sala?

Roberto: Nesse trabalho nós não podemos entrar no espaço da violência. É uma coisa meio estranha.

Ignacio: Meio estranha.

Roberto: Não resolve eu entrar lá e bater em alguém.

Ignacio: Mas essa mulher estava matando a menina.

Roberto: A jovem. É.

Ignacio: Você ouviu o que estava acontecendo.

Nicolás: Ignacio.

Ignacio: $O$ quê?

Roberto: Eu já tinha visto essa menina em coisas assim. Deve ser por causa de onde anda se metendo.

Ignacio: Onde?

Roberto: É neonazi.

Ignacio: Neonazi.

Roberto: É uma coisa meio estranha, já vimos em outros países. Não se consideram neonazis, mas têm todas as características de um grupo nacionalista. Saem para linchar as pessoas de noite. Imigrantes, prostitutas, gays. Talvez o que você viu foi isso. (Para Nicolás)

Ignacio: Ah.

Nicolás: O quê?

Ignacio: Nada, agora a coisa muda de figura. Continua sendo horrível, mas muda um pouco.

Nicolás: E quem ligou agora?

Roberto: Alguém que quer se vingar.

Ignacio: Isso é muito grave, temos que chamar a polícia.

Roberto: Não vai acontecer nada.

Ignacio: Claro que vai!

Roberto: Não.

Ignacio: Disse que era neonazi?

Roberto: Disse.

Ignacio: Preciso fumar um cigarro. Vou chamar a polícia. (Sai) O cachorro?

Roberto: É inofensivo. (Fica sozinho com Nicolás) Quer tomar algo mais forte? (Pausa) O que meu pai fez?

Nicolás: Nada, é que sua mãe disse para você olhar seus irmãos. 


\section{Roberto: E?}

Nicolás: Não sei. Você é filho único.

Roberto: Sou.

Nicolás: E seu pai teve várias mulheres depois da sua mãe.

Roberto: Sim. Mas quando minha mãe dizia meus irmãos, ela se referia aos meus irmãos ou aos "irmãos"?

Nicolás: Como?

Roberto: Nada.

Nicolás: Sua mãe estava meio estranha antes de morrer.

Roberto: Por que todo mundo diz isso?

Nicolás: Sua casa estava sempre cheia de gente.

Roberto: Que gente?

Nicolás: Não sei. Um dia vi uns peruanos pintando a casa dela.

Roberto: Por quê?

Nicolás: Não sei. Depois uma mulher saiu com uma pasta na mão.

Roberto: De onde?

Nicolás: Da casa da sua mãe.

Roberto: Uma mulher peruana?

Nicolás: É.

Roberto: Por quê?

Nicolás: Não sei. Mas quando ela estava saindo, sua mãe falou algo no ouvido dela.

Roberto: Da peruana?

Nicolás: É.

Roberto: O que ela disse?

Nicolás: Autogestão.

Roberto: Autogestão? Olha só. Como você ouviu, se era segredo?

Nicolás: Li seus lábios.

Roberto: Por que estava lendo lábios?

Nicolás: Não sei.

Roberto: O que mais ela disse?

Nicolás: Não entendi, mas tenho certeza de que terminou com autogestão. Depois a beijou na testa.

Roberto: De quem?

Nicolás: Da peruana. Ela disse: "compa, já nos organizamos, não estamos unidas pelas bandeiras, estamos unidas pela vida".

Roberto: É um bom leitor de lábios, hein?

Ignacio: (Entra Ignacio) Roberto, pode vir aqui?

(Roberto sai. Nicolás fica sozinho. Ouve-se um grito de Roberto. Roberto entra chorando copiosamente com o cachorro nos braços. O cachorro está sangrando. Está morto. Roberto grita de dor.)

(Eugenia entra com os olhos inchados e vermelhos)

Eugenia: "Estou fugindo do medo. Medo do homem branco". Com esta frase fui embora da Grécia. Vou aonde os bárbaros moram. Onde as pessoas olham para dentro. Onde há reuniões de vizinhos cheias de copos de plástico. Cheias de um frio de mer- 
da, de gente com vontade de falar, gente que explica todos os dias por que estamos aqui. Todos os dias. Ou seja, uma vida de merda, uma vida sem sentido? Sim. Ninguém disse que teria sentido. Nesse lugar, o povo obedece, porque o povo é quem manda. Então, os discursos de cada reunião de vizinhos estão repletos de tristeza? Estão. Estão cheios de sindicados? Também. Tem muito velho que fala além da conta? Tem. Ninguém disse que aqui não ia ter velho. Tem copo de plástico? Tem. Vai ter idiota fazendo discurso de ódio? Claro. Ninguém disse que não haveria inimigos. A pergunta é se o inimigo tem sempre a mesma cara. A pergunta é se o inimigo nunca muda de cara e se também são meus inimigos os que se parecem ao meu inimigo. Depois, várias perguntas que se respondem sozinhas. Esta é a organização que vai nos levar ao fim da propriedade? Sempre vai ter um moleque de 18 anos que vai nos acusar de ficar em cima do muro? Os países vão acabar? Vamos tentar comprar um fogão? Não há estrelas aqui, nem bandeiras simétricas, nem cores da pátria, onde o que une as pessoas é o mesmo salário, o mesmo bairro, as mesmas doenças, os mesmos terremotos. A quantidade de buracos no corpo. Não tem nada mais solidário do que os corpos humanos que trepam, respirando em suas bocas, que são desajeitados movendo-se na cama, enrolando as pernas ao se penetrarem, que não sabem o que fazer com o cabelo do outro, que pedem desculpas quando entram no buraco errado, o amor é assim. E nesse lugar não se diz "meu amor, amorzinho, minha vida", ao contrário, se grita muitas vezes "a vida!". E com um grande ponto de interrogação. Por isso vim ao Chile, procurando esse lugar, procurando terras bárbaras, porque li que nas florestas há assembleias que duram dois dias, e me contaram que nessas terras atrás das Virgens desenhavam sóis. Vim porque queria saber como os bárbaros se organizam, ver como é uma democracia sem brancos, ver os camponeses gritarem "autonomia!" Este é um território! Mas não é nosso território, porque aqui não existem propriedades nem fronteiras, aqui estão os irmãos. Tragam os violões! Cantemos canções em dialetos com poucas vogais! Vamos gerir nossos próprios meios de produção com material alheio! Atiremos nos que se apropriaram das nossas matérias-primas! Aqui estão os bárbaros! As irmãs e os irmãos bárbaros que nos olham por dentro. Aqui estamos! E cheguei ao Chile.

Roberto: A grega.

Ignacio: A grega.

Eugenia: A grega está assim. Acabada. (Aproxima-se de Roberto) Não consigo dormir. Estou falando assim há dias. Este é meu quarto monólogo, desde que saí de casa. Tentei dormir. Mas não consigo. Devem ser os antidepressivos. Vejo a Claudia toda hora.

Ignacio: Claudia?

Eugenia: A jovem que morreu, Roberto contou?

Ignacio: Sim, veja... O cachorro de Roberto acabou de ser assassinado.

Eugenia: O cachorro de Roberto?

Ignacio: A polícia está a caminho.

Eugenia: $O$ cachorro de...

Ignacio: Acho que é melhor Roberto ficar tranquilo agora. Não é nada pessoal.

Eugenia: Prefiro ficar. 
Ignacio: É?

Eugenia: Está assim por causa do cachorro?

Ignacio: Como?

Eugenia: Está assim por causa do cachorro?

Ignacio: Sim, ele gostava muito dele.

Eugenia: Nunca tinha visto ele chorando.

Ignacio: Ele falou pra gente.

Eugenia: $O$ que ele falou?

Ignacio: Que não chora nunca, que nunca bate em ninguém.

Eugenia: Roberto, Elias ficou sabendo que vai despedi-lo.

Nicolás: Quem é Elias?

Eugenia: $O$ ex-policial que trabalha conosco.

Nicolás: Por que vão despedi-lo?

Eugenia: Leva muito a sério a dinâmica de papéis.

Nicolás: É ex-policial?

Eugenia: É, ele se tranca com as pessoas em quartos escuros, é meio violento. Acho que aconteceu algo que o deixou meio bruto.

Nicolás: Por que se tranca em quartos escuros?

Eugenia: Eu sei lá. Quem é você?

Nicolás: Sou primo do...

Ignacio: Basta! Roberto está mal!

Eugenia: Me desculpem. Sou uma estúpida. Uma estúpida. (Começa a caminhar em direção a ele e nisso, toca o cachorro com o pé) Roberto.

Roberto: Ei, não faça isso! (Empurra Eugenia, ela fica olhando para ele) Como se atreve, sua louca?

Eugenia: Desculpe.

Roberto: Não faça isso de novo.

Ignacio: Roberto está um pouco...

Roberto: Um pouco o quê?

Ignacio: Afetado.

Ignacio: A gente nunca sabe como reagir em momentos ruins, ele não teve a intenção.

Roberto: Claro que não tive!

Nicolás: Faz quanto tempo que chamou a polícia? (Para Ignacio)

Ignacio: Sim. (A Nicolás)

Eugenia: Fique tranquilo. Fez pelos outros muito mais do que qualquer outra pessoa faria.

Roberto: Não sei, quando me fazem isso, não sei.

Eugenia: $O$ quê?

Roberto: (Olha para o cachorro) Isto que você está vendo sou eu. É tudo o que tenho. Não tenho pai, não tenho mãe. Não tenho irmãos! Tudo o que tenho é isto, entende? Eugenia: Claudia era um anjo.

Ignacio: Um anjo?

Eugenia: Era. 
Ignacio: Neonazi?

Eugenia: Era, Roberto sempre vê esses anjos atrás dos demônios. Esses amigos atrás dos inimigos.

Roberto: Não há amigos nem inimigos. Há seres humanos. Chama-se ver o outro. Empatia. Nosso trabalho consiste nisso, Eugenia.

Eugenia: Mas no nosso trabalho tem um inimigo. Você mesmo sempre diz que o inimigo é quem começa a violência.

Roberto: Mas quando trabalhamos com eles, deixam de ser nosso inimigo.

Eugenia: Então você faz o inimigo acreditar que é seu amigo?

Roberto: O quê? Não tento mostrar que é meu amigo, tento mostrar que é um ser humano que tem a mesma dignidade dos outros.

Eugenia: Então, por que matou a Claudia?

Roberto: Quem?

Eugenia: Você.

Roberto: Eu? Eu estava... o quê?

Eugenia: Estou perguntando por que matou essa criança.

Ignacio: Roberto não matou ninguém.

Eugenia: Matou sim, a Claudia.

Ignacio: Você estava elogiando ele agora mesmo.

Eugenia: É a pessoa mais bondosa que conheço.

Ignacio: Qual o seu conceito de bom?

Eugenia: Só quero saber isso, Roberto. Por que deixou a Claudia morrer? Me diga e vou embora.

Roberto: Eu... Eugenia.

Eugenia: Por que não entrou na sala?

Ignacio: Entrou ou não entrou? (Para Roberto)

Roberto: Quando?

Eugenia: Enquanto a menina era morta.

Roberto: Nós dois entramos.

Eugenia: Não.

Ignacio: Ele demorou um pouco, mas...

Eugenia: Não. Roberto ficou fora da sala...

Ignacio: Mas você tinha dito que...

Eugenia: Eu ouvi os gritos e corri até...

Ignacio: A sala que... E você estava...

Roberto: Nesse momento lá fora...

Eugenia: Dava para escutar os gritos do quintal e...

Nicolás: Parece que então Roberto entrou.

Eugenia: Roberto ficou sentado.

Roberto: Não, foi quando me levantei e...

Ignacio: Você entrou...

Roberto: Quero dizer, percebi que...

Eugenia: Roberto, tinha câmera. (Roberto fica em silêncio)

Ignacio: Você entrou ou não, Roberto? (Silêncio) 
Roberto: Não.

Nicolas: Por quê?

Roberto: Não sei. (Pausa) Acho que já pode ir embora, Eugenia. Já disse o que queria saber.

Eugenia: Não, eu não vim para isso.

Ignacio: Veio para quê?

Eugenia: Quero saber por que você me empurrou.

Ignacio: O quê?

Eugenia: Quero saber por que me empurrou.

Ignacio: Quando?

Eugenia: Quando encostei no cachorro.

Ignacio: Mas isso foi agora.

Eugenia: Foi.

Roberto: Você empurrou meu cachorro como se fosse um saco de lixo. Como esperava que reagisse?

Eugenia: Assim.

Ignacio: Como?

Eugenia: Espero que você reaja assim.

Ignacio: Se alguém mexe com algo meu, eu defendo. Se alguém encostar nos meus filhos, eu acabo com ele.

Nicolás: Nossa!

Ignacio: Eu acabo com ele! Você não faria o mesmo?

Eugenia: É, Eugenia, não faria o mesmo? (Pausa) Responda. (Pausa) Responda, Eugenia.

Ignacio: $O$ quê? O que foi?

Eugenia: Eu abandonei meus filhos.

Ignacio: $O$ quê? Onde?

Eugenia: Na Grécia.

Ignacio: Quantos anos têm?

Eugenia: $O$ mais velho, 12. O outro, 7.

Ignacio: Nossa! Por quê?

Eugenia: Fiz coisas que não deveria. Apareceram coisas para mim.

Nicolás: Tipo o quê?

Eugenia: Um pênis.

Nicolás: Ok.

Eugenia: Não é fácil. Já apareceu uma vagina para você?

Nicolás: Não muito, ultimamente.

Eugenia: Vai ver quando aparecer um pênis. Mudou minha vida para melhor.

Nicolás: Então qual é o problema?

Eugenia: $O$ pênis não era do meu marido.

Nicolás: E o que seu marido fez?

Eugenia: Me pegou com o outro pênis. E saiu de casa.

Nicolás: E seus filhos?

Eugenia: Descobriram o que aconteceu. 
Nicolas: Nossa.

\section{Eugenia: É.}

Nicolás: E por que os abandonou?

Eugenia: Porque se escondiam de mim. No dia em que fui embora, achei-os escondidos no cesto de roupa suja. São crianças. Não sabem se esconder.

Nicolás: É verdade.

Eugenia: Vocês não são donos do meu corpo, eu disse. Parti o coraçãozinho deles. Começaram a chorar e correram até a cozinha. Fui atrás deles, me apoiei na geladeira e disse: vou embora. Vocês não querem uma mãe. Vocês querem A mãe. Vocês querem a Virgem Maria. Volto quando quiserem ver a Eugenia. Vocês querem ser meus filhos, mas quero que sejam meus irmãos. Qual o problema? Olhem para mim. Querem que tire minha roupa, que faça um corte na barriga para verem de que sou feita? Então, como gesto simbólico, joguei fora todos os ímãs de bandeiras de países que estavam na geladeira. Foi difícil, porque essas merdas grudam de novo. Fui embora. Tremendo. Cantando. O coração bombeando. Às vezes, os valentes são covardes, eu pensei, com os olhos fora de órbita. E fui embora falando sozinha, "adeus Europa, não vou lutar para manter o medo do homem branco vivo, por isso vou aonde moram os bárbaros. Vou para onde as pessoas não se acham donas da terra, donas das pessoas. Vou para a floresta lutar, onde as assembleias duram dois dias, até que todos sejam ouvidos, onde todos são pais e mães e irmãos. Vou embora para onde as pessoas atrás das Virgens desenham sóis". E cheguei ao Chile. E não sei. Sempre que digo isso, me dá um branco. Cheguei ao Chile. Não sei o que falar depois.

Ignacio: Eugenia, isto é uma reunião de primos.

Eugenia: Já vou embora. Só quero que Roberto me diga por que me empurrou. Ignacio: Ele já falou que não pensou, foi e fez.

Eugenia: Claro. Podia ter não pensado também quando estavam matando a Claudia. Roberto: Ela quer que eu aceite que deixei essa menina, essa jovem, morrer.

Eugenia: Essa criança. Quero que aceite que não teve empatia. Que para você, tem gente que merece morrer. Que você prefere defender um cachorro a um ser humano. Ignacio: Eugenia, talvez concorde com você, mas Roberto nos chamou para uma festa de primos.

Roberto: Eu não os chamei para uma festa de primos.

Ignacio: Não? (Seus olhos brilham de tristeza)

Roberto: Eu os chamei porque quero entender as coisas que minha mãe disse.

Eugenia: O que a mãe dele disse? (Sussurrando para Nicolás)

Nicolás: Para ele olhar seus irmãos. (Sussurrando)

Eugenia: Mas ele é filho único. (Sussurrando)

Nicolás: É, a gente parou aí também. (Sussurrando)

Roberto: E você, ainda por cima, concorda com ela?

Ignacio: Eu disse talvez.

Roberto: Ah, talvez concorde. E como é isso de concordar "talvez", Ignacio? Como alguém concorda talvez, Ignacio? O que significa isso, Ignacio?

Ignacio: Tente não falar Ignacio tantas vezes, por favor.

Roberto: Não estão vendo que estamos diante de um cadáver? Será que seus olhos 
não veem que estamos diante de um morto? (Pausa)

Eugenia: Claro, os mesmos olhos que viram morrer...

Roberto: Uma neonazi! Uma neonazi! É, vai saber. Talvez a vida de um cachorro valha mais que a de um ser humano.

(Elias entra)

Elias: (Vê o cachorro morto). Este é o cachorrinho do Roberto.

Eugenia: $O$ ex-policial.

Ignacio: $O$ ex-policial.

Elias: (Vê o cachorro morto). Esse é o cachorrinho do Roberto?

Ignacio: Olá, esta é uma reunião de...

Elias: Acabei de falar com a tia da Claudia.

Eugenia: Quando?

Elias: Agora mesmo. Eles querem lhe agradecer, Roberto, por tudo o que você fez por ela.

Eugenia: Sério?

Elias: É, Claudia estava envolvida com coisas estranhas há um tempo. Sentia uma raiva que a levou para o lado errado.

Ignacio: O lado neonazi.

Elias: Claudia não era neonazi.

Ignacio: Era o quê?

Elias: Uma menina provando coisas.

Ignacio: Coisas neonazis?

Elias: Era um jogo.

Ignacio: Um jogo neonazi?

Elias: Não sei. Às vezes só queremos fazer parte de algo. Ela também ficou muito triste com a morte da sua mãe, Roberto. (Para Roberto. Pausa)

Ignacio: Quem?

Elias: A Claudia.

Ignacio: A morte de quem?

Elias: Da mãe de Roberto. (Roberto olha pra ele sem entender)

Nicolás: Da mãe de...

Eugenia: Ah.

Ignacio: O quê? (Para Eugenia)

Eugenia: Já entendi.

Ignacio: O quê? (Para Eugenia)

Elias: Elas estavam muito próximas

Roberto: Quem? (Para Elias)

Nicolás: Você não sabia, Roberto?

Roberto: Oi? (Para Nicolás)

Elias: Estava quase morando com sua mãe.

Ignacio: Quem, gente?

Elias: Claudia estava ajudando sua mãe com coisas da casa.

Nicolás: Como se conheciam? (Para Ignacio)

Elias: E como a casa estava sempre cheia de gente, Claudia a ajudava na organização, 
com as compras, e sua mãe estava meio estranha, e...

Ignacio: Como Claudia chegou à casa da mãe de Roberto? (Para Eugenia)

Elias: Ela queria conhecer o pai dela. Uma vez fiz o pai dela na dinâmica de papéis.

Ignacio: Ah, você participa da dinâmica.

Elias: Isso, eu participo, sou eu que... então ela me disse que foi conhecer o seu pai, então foi à casa de sua mãe. (Para Roberto)

Nicolás: O pai de...

Elias: Roberto.

Ignacio: Por que ela foi procurar o pai de Roberto?

Elias: Porque Claudia queria saber quem era o pai dela, foi quando encontrou a mãe de Roberto. Ela lhe disse que eles estavam separados há muito tempo.

Nicolás: E o pai de Claudia? (Para Ignacio)

Elias: De qualquer forma, Roberto, quero que saiba que isso também me afeta muito, porque eu nunca perdi uma irmã. (Pausa. Roberto fica em silêncio. Ignacio se aproxima e diz algo secretamente a Elias)

Elias: Desculpe. Desculpe. Puxa. Eu sei consertar isso.

Ignacio: Sabe?

Elias: Podem me dar uma última chance?

Ignacio: Pra quê?

Elias: Já sei que vão me mandar embora. Eugenia me contou. Porque eu levo a dinâmica muito a sério.

Eugenia: O que você vai fazer, Elias?

Elias: Uma dinâmica de papéis.

Ignacio: Acho que não é o momento, meu amigo.

Elias: (Chega perto de Ignacio). Acho que posso ajudá-lo.

Eugenia: Não dá, Elias.

Elias: (Olha para Roberto, que está imóvel e mudo) Roberto, qual era o nome do seu cachorro?

Ignacio: Não, não.

Elias: Qual era o nome do cachorro?

Eugenia: Cristóvão Colombo.

Elias: Quem você quer que eu seja, Roberto?

Eugenia: Elias, acho que já chega.

Elias: Me escute. Sou Cristóvão Colombo.

Nicolás: Como? Ele também?

Ignacio: Espere.

Elias: (Fica muito sério e aproxima seu rosto do de Roberto). Estou aqui. Não fui a lugar algum. Continuo sendo seu cãozinho.

Ignacio: Elias?

Elias: Eu já subi. Tem um céu para os cachorros.

Ignacio: Acho que isso não está dando certo.

Elias: Espere.

Ignacio: Seu jogo não funciona, meu caro.

Nicolás: Quero falar com Cristóvão Colombo. 
Ignacio: Não, Nicolás.

Elias: Tudo bem. No céu, também posso mexer meu rabinho.

Nicolás: Não, não. Com Cristóvão Colombo.

Elias: $O$ quê?

Ignacio: É que ele não vê o véu. (Faz o gesto com as mãos)

Eugenia: Alguém sabe se a polícia já vem?

Ignacio: Elias, não sei se você consegue fazer isso. Acho que precisa de preparo.

Elias: Posso fazer qualquer papel, o que você quiser.

Ignacio: Acho que não.

Elias: É sério, tente.

Ignacio: Está bem. Você é minha mãe.

Elias: "Faz muito tempo que não conversamos". (Ignacio fica estupefato e com os olhos chorosos)

Nicolás: Eu! Por que os chamaram de índios?

Elias: Por que os chamamos de índios?

Ignacio: Ele quer falar com Cristóvão Colombo.

Elias: Ah, claro, Cristóvão...

Ignacio: Isso.

Elias: Como?

Eugenia: Você disse que podia fazer qualquer papel.

Nicolás: Por que índios, Cristóvão?

Elias: Bem, a coisa não estava fácil.

Nicolás: Certo, mas por que índios?

Elias: Queríamos chegar às Índias.

Nicolás: Mas acharam outra coisa.

Elias: Isso mesmo.

Nicolás: Mas por que índios?

Elias: Tente me entender também. Eu levava um barco cheio de gente desconhecida, gente com fome. Gente que estava vendo um mapa inventado das Índias e diziam: "isto é meu, isto é meu". E não sei. Vinha um cheiro que não era exatamente de rosas. Eu disse, ou chegamos às Índias ou a Terra é plana; de duas, uma. Não deu nem uma nem outra. O que eu ia falar para eles? As pessoas não aceitam bem esse tipo de notícia. Eu pensei, vamos chamá-los de índios, por enquanto.

Nicolás: Mas já passaram mais de 500 anos.

Elias: É, o negócio se estendeu um pouco.

Eugenia: Eu quero falar com meus filhos.

Elias: Com qual?

Eugenia: Com o de 12.

Elias: Pronto. (Se prepara). Oi.

Eugenia: Oi, tudo bem?

Elias: Aqui.

Eugenia: Como você está?

Elias: Aqui, mamãe.

Eugenia: Mamãe? 
Elias: Não está fácil me acostumar com a vida sem você. Estou cuidando do meu irmãozinho.

Eugenia: Está bem, obrigada.

Ignacio: Vão embora! Obrigado, mas vão embora.

Elias: Deixe-me consertar isso, Roberto. Tem que ver onde está seu medo. Tem que procurar o que está debaixo da roupa. Tem que ver onde está a ferida e apertar. Por que me deixou morrer? (Para Roberto)

Ignacio: Quem é? (Sussurrando para Eugenia)

Eugenia: Acho que é a Claudia. (Sussurrando para Elias)

Roberto: Não sabia que você era minha irmã.

Elias: Quando a via, não saíam palavras da minha boca.

Roberto: Eu sentia que te conhecia de algum lugar. Suas sobrancelhas são iguais às do meu pai.

Elias: Eu não o conheci.

Roberto: Sua mãe não the disse como ele era?

Elias: Também não conheci minha mãe. Um dia, chegou uma carta dizendo quem era meu pai e onde morava. Então fui procurá-lo e achei sua mãe.

Roberto: Como são as coisas.

Elias: É.

Roberto: $O$ que você fez quando minha mãe morreu?

Elias: A vida ficou difícil quando sua mãe morreu. As pessoas diziam que eu tinha hálito de órgãos. Quando aparecem as coisas para você, tudo fica diferente, eu achei que estava bem, mas aconteciam coisas estranhas comigo. Acabava de almoçar, e em vez de jogar a colher suja na pia, jogava no lixo, sabe? E as pessoas olham pra você e dizem... "Nossa, os olhos dela foram pra dentro. Parecia um cano furado, a menina. Cheira como se alguém tivesse lhe feito um corte na tripa, deixando os órgãos no ar". E eu ouvia minha tia depois do almoço de domingo, falando baixinho... "A Claudia anda linchando as pessoas, virou antiperuana, antiviado, nossa!". Sua mãe me explicou que quando você é rejeitada, vira um bicho estranho. Se fosse um cachorro já teria morrido, mas a gente continua aqui.

Roberto: Como é que são as coisas.

Elias: É, quando aparecem as coisas, a vida só segue, e eu tentei ajudar sua mãe com os imigrantes.

Roberto: Com a autogestão?

Elias: Isso. Sua mãe ficou estranha quando soube que seu pai era mulherengo. E falava delirando que as pessoas deviam se organizar, que não devemos esperar ajuda de ninguém, que a esperança nos afasta da vida, que não estamos unidos por bandeiras, o que nos une é a vida. É o que sua mãe dizia.

Roberto: Mas você é neonazi. O que fez com os peruanos?

Elias: Quando a polícia nos pegava, sempre procuravam suásticas no corpo ou cabeças raspadas, mas nunca acharam nada.

Roberto: Então você não era neonazi.

Elias: Só queria provar essa sensação.

Roberto: Que sensação? 
Elias: A sensação de vocês, de ser um cidadão. De sentir que, pelo menos, uma vez, posso dizer que minha vida é minha. Mesmo que seja um pedacinho de terra. Sentir que tem gente que precisa morrer. É o que vocês fazem, ou não? Saber o que os famintos precisam sem nunca ter sentido fome. Saber como impedir a violência sem ter nunca que pegar uma arma. Não é isso? Defender que isto começou assim, que esta terra nasceu com donos. Que a gente saiu do útero e já era assim. É o que vocês fazem, não é? Democratizar?

Roberto: Acho que você está confundindo as coisas.

Elias: Dá no mesmo.

Roberto: Por quê?

Elias: Porque já estou morta.

Roberto: Queria ficar sozinho agora.

Elias: Acho que é um pouco perigoso.

Eugenia: Roberto está pedindo, gente.

Elias: Ele foi ameaçado.

Eugenia: Mas já fizeram o que queriam.

Elias: E como sabemos se já acabou?

Ignacio: É, como sabemos?

Eugenia: Já mataram o cachorro.

Ignacio: Não.

Eugenia: Como não?

Ignacio: Já, quer dizer. Não vai ser bom ouvir isso. Cristóvão Colombo morreu, certo? Porque eu... como poderia dizer? Eu o matei. Em outras palavras, eu o matei. Bem, nas mesmas palavras.

Elias: Por quê?

Ignacio: Não vai ser legal de ouvir. Quando ligaram, fiquei muito assustado. Pensei que eram os neonazis. Então saí e pensei: "vamos castigá-lo com seus seres queridos".

Elias: Por que pensou isso?

Ignacio: A ameaça foi assim.

Elias: A ordem da frase é estranha, não é?

Ignacio: É. Então pensei, "seres queridos". Essa frase atravessou minha mente. E minhas mãos começaram a suar. E depois pensei em "olhe os seus irmãos", tudo dando voltas na minha cabeça. Olhava para o cachorro e as mãos tipo... (Faz barulho de agitação)

Elias: Está bem, vamos para o final.

Ignacio: Então, sem pensar, peguei o Cristóvão Colombo e o matei. Quando o cachorro estava agonizando, cravei-o no portão. Assim. (Faz o gesto)

Elias: Mas agora ele não está cravado no portão.

Ignacio: É que não deu certo. Pensei que seria mais fácil. Quando tentei craválo, não consegui perfurá-lo com as pontas. Se você olhar bem, as marcas estão aí. (Apontado para a barriga do cachorro)

Eugenia: Por que queria cravá-lo no portão?

Ignacio: Para os neonazis dizerem: "alguém já fez o serviço pra gente". 
Eugenia: Alguém já fez o serviço pra gente?

Ignacio: Claro, eles veriam o cachorro cravado no portão, pensariam que alguém já tinha feito o serviço e iriam embora, fazer mais coisas neonazis.

Eugenia: Matar o cachorro por quê?

Ignacio: Porque Roberto disse que era o único ser querido que the restava no mundo. Eugenia: Então você matou o único ser querido que the restava no mundo? E o cachorro nem ficou lá.

Ignacio: Não, claro, agora o cachorro está aqui.

Nicolás: Quer dizer que podem vir agora?

Ignacio: Quem?

Nicolás: Os que ameaçaram Roberto.

Elias: Mas chamaram a polícia ou não?

Ignacio: Não os chamei.

Eugenia: Ah, porque você...

Ignacio: É.

Eugenia: E o cachorro está aqui.

Ignacio: Está.

Elias: Espere.

Ignacio: $O$ quê?

Elias: Vou resolver isso.

Ignacio: Que merda você vai resolver? Estão vindo nos matar.

Nicolás: Ignacio, um pouco mais de respeito, por favor.

Ignacio: (Para Elias.) Estou falando com ele.

Nicolás: Mas o que isso tem a ver com Cristóvão Colombo?

Ignacio: Estou falando com ele.

Nicolás: Também está falando comigo!

Ignacio: Não estou falando com você.

Nicolás: Agora está.

Ignacio: Ninguém pode conversar com você!

Nicolás: Hoje conversei muito com todo mundo.

Ignacio: Você não entende.

Nicolás: Por que não entendo?

Ignacio: Porque está imbecil! Por isso! Porque tropeçou e não entende mais as coisas.

Nicolás: Que coisas?

Ignacio: Isto! (Faz o gesto com a mão). Está vendo?

Nicolás: $O$ que é isso?

Ignacio: É um véu.

Nicolás: Mas estou vendo o que você está fazendo.

Ignacio: Não, você não está vendo, Nicolás. Não está. Ele não é Cristóvão Colombo, está entendendo?

Nicolás: Mas ele mesmo disse.

Ignacio: Não, não, não!

Nicolás: É, ele me contou por que chamou os índios de índios. 
Ignacio: É, imbecil. É o que estou dizendo. Ele não é Cristóvão Colombo. E agora uns neonazis estão vindo nos matar!

Nicolás: Por que vão nos matar?

Ignacio: Porque são neonazis! (Aponta para Roberto) Ele é inimigo deles. E se eles quiserem, ele, você, ela e eu somos a mesma coisa.

Nicolás: Por quê?

Ignacio: Porque veem a vida assim! (Faz o gesto.) Assim! Entendeu? E vão cravar você numa grade porque veem a vida assim! É o véu, seu imbecil! Essa é a dona de casa, tanto faz se está ou não em casa agora, este é o negro, o peruano, a prostituta. Os casos são contados assim: começam dizendo, ontem vi matarem uma puta. Contam as histórias assim. Você coloca o véu e depois conta. Funciona assim também com as notícias. Mas tanto faz agora, porque neste instante vão entrar uns nazis aqui, vão quebrar esta garrafa, vão pegar sua barriga e vão fazer uma suástica nela com a garrafa quebrada. E eu vou chorar, só que para dentro. E você vai pôr uma mão na cabeça e a outra nos testículos e vai se perguntar "por que eu? Por quê?" E eles vão dizer "este é o véu, somos neonazis, este é o véu, entendeu?"

Elias: Temos que chamar a polícia agora.

Eugenia: Temos?

Elias: Sim.

Eugenia: Certo, eu chamo. (Eugenia sai para ligar). Esperem. Claudia não era neonazi. Elias: E daí? Vai chamar a polícia!

Eugenia: Sim, mas ela era neonazi?

Elias: Não, Eugenia. Não era neonazi. Era uma chilena como qualquer outra. Vá chamar. (Eugenia sai para ligar)

Nicolás: Eu não quero morrer assim.

Ignacio: Tanto faz, porque vão nos matar agora.

Elias: Roberto, sei que não é o melhor momento, mas queria falar sobre o trabalho.

Nicolás: Mas assim não.

Nicolás: Assim como?

Elias: Sei que aconteceram muitas coisas hoje.

Nicolás: Sem poder ver o véu.

Ignacio: Tanto faz, porque agora vão entrar uns neonazis lançando garrafas de cerveja e uma delas vai arrancar seus dentes, que vão cair formando uma suástica.

Nicolás: Podem fazer isso?

Ignacio: É modo de dizer, Nicolás. Por isso você não vê isto. (Faz o gesto) / (Eugenia entra)

Elias: É assunto de trabalho, Roberto. Ando meio complicado.

Nicolás: Deixe-me vê-lo antes de morrer.

Ignacio: $O$ quê?

Nicolás: $O$ véu.

Elias: Preciso desse trabalho, não me deixam voltar para a delegacia. O que você achou do último trabalho que fiz?

Roberto: Achei bárbaro.

Elias: O que quer dizer com bárbaro? 
Roberto: Falei bárbaro?

Elias: Falou.

Roberto: É.

Ignacio: Me passe uma garrafa, Nicolás.

Nicolás: $O$ quê?

Ignacio: Me passe uma garrafa, Nicolás.

Elias: Mas quando diz bárbaro, o que quer dizer?

Roberto: Não sei, uso quando me convém.

Ignacio: Veja, aqui tem uma pessoa. (Pega um copo)

Nicolás: Certo.

Eugenia: Pode repetir o que disse?

Roberto: Que merda vão me perguntar agora?

Eugenia: Você disse que usa "bárbaro" quando...

Roberto: Quando me convém, não sei nem por que eu disse. Por favor, por favor. Ignacio: (Pega o outro copo). Aqui tem outra pessoa. E este (pega a garrafa de vinho) é o véu. Este véu está em todas as relações que esta pessoa tem com a outra.

Nicolás: Mas posso tirar o véu daqui. (Arrasta a garrafa)

Ignacio: O que acabei de falar, Nicolás? Não me faça perder tempo. Então, você acha que esta pessoa pode se relacionar com a outra sem este véu?

Nicolás: Quer dizer, eu entraria por aqui. (Coloca o copo ao lado da garrafa)

Ignacio: Não. Não pode pular a garrafa, Nicolás. Não pode pular a garrafa. O véu não está aqui. Ou seja, esta garrafa não está entre as duas pessoas, está dentro de você.

Nicolás: Tem uma garrafa dentro de mim?

Ignacio: Não. Puta merda. Está entendendo que isto não é uma garrafa? (Pega a garrafa)

Nicolás: Não é uma garrafa? Que mundo é este?

Ignacio: É uma garrafa!

Nicolás: Não, sério, não brinquem comigo. De verdade.

Ignacio: É uma garrafa! É uma garrafa que estamos usando como véu.

Nicolás: Está bem.

Ignacio: Certo. E este véu de merda está sempre mudando. E esta pessoa olha diferente para a outra de acordo com o véu que predomina em cada época. Entendeu? Entendeu que é o véu que muda? Me diga. Por que está me olhando assim? Já entraram? Já te mataram?

Nicolás: $O$ quê?

Ignacio: Entendeu?

Nicolás: Não.

Ignacio: Só muda o véu. As pessoas se olham de acordo com o véu que usam. Imagine que se encontram...

Nicolás: Um chileno, um peruano e um chinês.

Ignacio: É uma piada?

Nicolás: Não, então só um chileno e um peruano.

Ignacio: Acha que é hora de contar piada, Nicolás? Vamos ver se vai achar engraçado quando os neonazis entrarem de coturno e colocarem suas bolas nos olhos e no 
lugar de pupilas, mini-suásticas...

Nicolás: Não. Mas 500 anos atrás, esse chileno e esse peruano não podiam se olhar. Ignacio: Por que não?

Nicolás: Não havia países, então era outro véu.

Ignacio: Isso. Olha, isso mesmo.

Nicolás: Claro, porque quando se olha pelo véu, este copo é uma pessoa, mas também é todas as outras.

Elias: Olha, ele está entendendo.

Nicolás: Então ninguém viu a dona de casa vendo televisão, porque a veem pelo véu? E este véu pode ser destruído?

Ignacio: Não sei. Expliquei porque depois todo mundo pensa que você é meio burro. Nicolás: Mas você disse que os véus mudam.

Elias: É o que tento explicar com a dinâmica de papéis.

Nicolás: De novo com a dinâmica, Cristóvão.

Elias: (Anda até ficar na frente de todos.) Você tenta viver sua vida, mas às vezes aparecem algumas coisas. Aparece um buraco, uma irmã...

Nicolás: Ou um continente, por que não, Cristóvão?

Elias: Vamos usar o exemplo de Roberto. Um dia ele vai caminhando como todo dia, e de repente fica sabendo que seu pai não é quem ele pensava. (Bate de leve no coração). Depois ligam pra ele e avisam que tem que voltar para o Chile porque sua mãe está doente. Tutum. Tutum.

Nicolás: $O$ que é isso?

Elias: O pulso dele. Tutum.

Nicolás: Certo.

Elias: Então, chega ao Chile e pá!

Elias: A mãe dele morre.

Nicolás: Nossa! E aí?

Elias: Então Roberto se abala, anda em zigue-zague, e olha as pessoas meio silencioso, desconfiado, como quando um bebê encontra outro, mas tenta continuar aqui. Então diz que agora vai olhar para os cachorros, com eles lido bem, alguns reagem assim quando a vida aparece, pensa que é seu único ser querido, tenta seguir sua vida, mas pá, pá, pá!

Nicolás: Matam seu cachorro.

Elias: Isso. Aí ele fica no chão, a cara dele fica mais imbecil do que nunca, tem calafrios, tenta ficar em paz, mas está com muita raiva, e quando acontece isso, a pessoa fica perplexa, e pode ficar semanas ou meses assim.

Nicolás: Ou 500 anos, Cris. Não foi fácil para você também não.

Elias: Mas de repente ele se levanta confuso, com raiva e com muitas peças do quebra-cabeça faltando, sem saber como olhar, ele anda e sente zazum, zazum.

Nicolás: $O$ que é isso?

Elias: É o som dos seus órgãos ao andar. E começa a sentir o gosto deles, e percebe que a menina que deixou morrer, para piorar, é sua irmã, e fica entre a tragédia e o melodrama, e meio congelado, porque, claro, a gente é bicho estranho, outra espécie já teria morrido, mas a gente continua aqui, continua, não sabe por quê, mas 
continua, e nesse choque, Roberto, a gente percebe que nunca mais vai ser o mesmo. Nunca mais vai ser o mesmo, e isso dá medo, dá pavor, porque às vezes aparece a vida.

Nicolás: Por que isso vai destruir o véu? (Para Elias)

Eugenia: (Pega a garrafa) Claro, às vezes aparece a Europa.

Elias: (Para Nicolás). Porque às vezes o véu te rejeita, te expulsa da vida. Mas a vida segue. E aí seus olhos caem diante dos seus olhos.

Nicolás: Temos olhos diante dos olhos?

Elias: E você volta a ver. E o medo muda de cara. O inimigo muda de cara. Para isso serve a dinâmica de papéis.

Nicolás: Para quê?

Elias: Para mudar a cara do inimigo.

Ignacio: Vou falar a verdade. Nunca vi um neonazi. Me contaram, mas eu nunca vi. Então eu me abro para o que entrar por esta porta. Não vou cometer o mesmo erro. Que venha o que vier.

Eugenia: Não vai chegar ninguém. Claudia não era neonazi.

Ignacio: Mas fazia coisas neonazis.

Eugenia: Mas não era neonazi.

Nicolás: Então quem vai entrar por essa porta para nos matar?

Eugenia: Ninguém vai entrar, porque eu que fiz a ameaça. Liguei para Roberto várias vezes, porque estava mal. Estou muito mal, rapazes. Ele não me atendia, então liguei de outro número e ele atendeu. Fiquei com tanta raiva, que o ameacei para lhe fazer medo, e como improvisei a ameaça, elaborei mal a frase, por isso saiu meio estranha. Quando cheguei, vi que alguém tinha matado o cachorro e pensei, "alguém adiantou o serviço".

Nicolás: Então quem tem matado os imigrantes, as prostitutas? Você disse que os neonazis veem que um desses são todos os outros. Os neonazis veem a vida assim, ou não?

Ignacio: Veem.

Nicolás: E como nós vemos a vida?

Ignacio: Então ninguém vai entrar por essa porta. (Silêncio)

Roberto: Vou enterrar Cristóvão Colombo.

Nicolás: Ninguém pode enterrar Cristóvão Colombo. Ele vai nos acompanhar para sempre. Nunca mais seremos os mesmos.

Ignacio: Está falando do cachorro, Nicolás. (Pausa). Vamos com você. Era pra ser uma noite de primos.

(Os primos saem. Elias fica sozinho com Eugenia)

Elias: Também vou embora. Eugenia? Preciso saber se amanhã vou ao trabalho ou não. O que Roberto quis dizer?

Eugenia: Com o quê?

Elias: Com "eu acho bárbaro".

Eugenia: $O$ quê?

Elias: Ele disse que achava bárbaro, quando perguntei sobre o que fiz agora. $\bigcirc$ que quis dizer com isso? 
Eugenia: Não sei.

Elias: Bárbaro. O que quis dizer?

Eugenia: Não sei. Bem, bárbaro pode significar muitas coisas.

Elias: Pode.

Eugenia: Bárbaro pode significar muitas coisas.

Elias: Sim, muitas.

Eugenia: Bárbaro pode significar muitas coisas.

Elias: Estou entendendo.

Eugenia: Bárbaro pode significar muitas coisas.

Elias: Estamos de acordo.

Eugenia: Fui embora da Grécia para ver como os bárbaros se organizavam.

Elias: E eu quero saber se amanhã vou trabalhar ou não.

Eugenia: Vou fazer você continuar. Ninguém faz o trabalho melhor que você.

Elias: Sério?

Eugenia: Sério, ninguém.

Elias: Obrigado. Na verdade...

Eugenia: Mas preciso de um último favor.

Elias: $O$ quê?

Eugenia: Preciso que faça a dinâmica comigo.

Elias: Quando?

Eugenia: Agora.

Elias: Que papel quer que eu faça?

Eugenia: $O$ do bárbaro.

Elias: $O$ quê?

Eugenia: Quero que faça o papel do bárbaro.

Elias: Qual é o papel do bárbaro? Não sei se consigo, Eugenia.

Eugenia: Disse que podia fazer qualquer papel.

Elias: Está bem.

Eugenia: Olá.

Elias: Olá.

Eugenia: Você é um...

Elias: Sou.

Eugenia: Estou um pouco nervosa.

Elias: Acontece.

Eugenia: Acho que estão seguindo o caminho errado.

Elias: Quem?

Eugenia: Vocês, os bárbaros. Estão errando de inimigo. Estão vendo seus irmãos como inimigos.

Elias: Meus irmãos?

Eugenia: Os bárbaros. Pensei que a vida era o que os unia. Os mesmos salários, os mesmos bairros, as mesmas doenças.

Elias: Você acha?

Eugenia: Terão que criar seus próprios bárbaros.

Elias: Você acha? 
Eugenia: Acho. Por que não? Para não desaparecerem. Vocês não são mais vistos por aqui.

\section{Elias: Sério?}

Eugenia: São como um buraco na neve.

Elias: Um buraco na neve?

Eugenia: Estão brancos por dentro. Como um picolé de baunilha.

Elias: Olha só.

Eugenia: Não estão mais unidos pelo mesmo salário, pelo mesmo bairro, pelas mesmas doenças.

Elias: Sei.

Eugenia: E deveriam estar unidos pelos salários.

Elias: Sim, Eugenia.

Eugenia: Então o que une os bárbaros? Sei que a frase "isso é meu" é estranha para vocês. Mas já a aprenderam. Vocês deveriam perguntar... "Quem roubou o sol? Quem roubou o mar? Quem roubou a terra? A terra onde os bárbaros podiam gritar: autonomia dos povos! E com os olhos sangrando gritar: eis o nosso inimigo!"

Elias: E quem é você para dizer quem é nosso inimigo?

Eugenia: Alguém que percebeu que esta terra é de vocês. Esta é a terra que vocês têm que defender. Esta é a terra que vocês têm que defender.

Elias: Mas esta terra não é nossa.

Eugenia: Por quê?

Elias: Porque nós não temos terra.

Eugenia: Então onde moram os bárbaros?

Elias: Dentro de vocês.

\section{Referências}

BONOBO, Cia. Texto de apresentação do grupo. Disponível em: https://bonoboteatro.wixsite.com/bonoboteatro Acesso em: 19 jun. 2019.

CINTAS, Jorge Díaz. La traducción audiovisual. El subtitulado. Salamanca: Biblioteca de Traducción. Ediciones Almar, 2001.

GONÇALVES, Luciana; MANZI, Pablo. Correspondência eletrônica. 22 - 24 abr. 2019.

KOCH, Ingedore V. O texto e a construção dos sentidos. Parte II: A construção do sentido no texto falado. São Paulo: Contexto, 2001.

MACHADO, Simone dos Santos. Linguagem formal e modelos cognitivos idealizados: um estudo sócio-cognitivo na tradução para legendas. Fortaleza, 2007. Dissertação (Mestrado em Linguística Aplicada) - Universidade Estadual do Ceará.

MANZI, Pablo. Texto integral da peça: Dónde viven los bárbaros. Dramaturgia: Pablo 
Manzi. Arquivo digital, PDF, recebido de Lygia Santos, da Frames, empresa responsável pela legendagem eletrônica do FIT-BH 2018. Correspondência eletrônica. 05. set. 2018.

MANZI, Pablo. La escritura vigilada y colectiva de Pablo Manzi in La Tercera. Culto, por Pedro Bahamondes. Periódico de circulação diária. Chile, nov. 2018. Disponível em: http://culto.latercera.com/2018/11/18/pablo-manzi-tu-amaras/ Acesso em: 19 jun. 2019.

Recebido em: 20/06/2019

Aprovado em: 14/07/2019 